\title{
A review of records and research actions for the Critically Endangered Beck's Petrel Pseudobulweria becki
}

\author{
JEREMY P. BIRD, NICHOLAS CARLILE and MARK G. R. MILLER
}

\begin{abstract}
Summary
The "Critically Endangered" Beck's Petrel Pseudobulweria becki has been recorded regularly in the Bismarck Sea during the past five years, but its nesting grounds are yet to be located. Previously, over 70 years elapsed between the collection of the original specimens in 1928 and 1929, and the next confirmed observations in 2007. We evaluate over 40 documented records of the species as well as recorded survey effort within the Bismarck Archipelago and Solomon Islands and we assess potential breeding areas as well as land and sea priority search areas. On current evidence, southern New Ireland, within the Bismarck Archipelago, remains the highest priority area to search for nesting colonies but other parts of the region also warrant further investigation. The species's distribution, population size and trends, ecology and threats are all poorly known, so prescribing conservation actions is difficult. As a starting point we identify the most important research actions to advance current knowledge, recognising that locating the nesting grounds of the Beck's Petrel remains the prime conservation priority for this species.
\end{abstract}

\section{Introduction}

Beck's Petrel Pseudobulweria becki is a small, contrastingly dark brown and white gadfly petrel, virtually identical in appearance to Tahiti Petrel P. rostrata but c.10-20\% smaller (Murphy and Pennoyer 1952, Shirihai 2008a). It was described as 'maybe extinct' (Bretagnolle et al. 1998) and 'extremely rare' (Brooke 2004) during a period of 77 years without a record following its discovery and a description based upon two birds shot at sea in the Bismarck Archipelago, Papua New Guinea in 1928 and east of Rendova, Solomon Islands in 1929 (Murphy 1928, Murphy and Pennoyer 1952). Beck's Petrel was rediscovered in 2007 (Shirihai 2008a), attracted to 'chum' at several locations in the Bismarck Sea north of New Britain, and around New Ireland, Papua New Guinea. A spate of records has followed, all at sea. To date, no breeding colonies have been discovered and their whereabouts remains uncertain.

In the past, the systematic treatment of the P. rostrata and P. becki complex (hereafter rostrata and becki) has been controversial (Bretagnolle et al. 1998). This paper follows Imber (1985), Sibley and Monroe (1990), Dickinson (2003), Brooke (2004), Onley and Schofied (2007) and BirdLife International (2012) in treating becki as a full species, but Jouanin and Mougin (1979), Harrison (1985), Marchant and Higgins (1990), Warham (1990), Carboneras (1992), and Christidis and Boles $(1994,2008)$ all treat becki as a subspecies of rostrata.

Beck's Petrel is classified as "Critically Endangered" on the IUCN Red List because a very small number of mature individuals are currently known, all within a single subpopulation which is suspected to have declined (BirdLife International 2012). Declines are postulated on the basis that predation by introduced cats and rats on its currently unknown breeding grounds has probably 
driven population declines (Birdlife International 2012). Unlike a number of other Critically Endangered gadfly petrels for which the level of search effort to date suggests they are genuinely very rare (e.g. Fiji Petrel P. macgillivrayi and Magenta Petrel Pterodroma magentae), the paucity of records of Beck's Petrel may be because there were relatively few searches prior to 2007 (BirdLife International 2012). Indeed, this pattern has already changed considerably with two recent surveys estimating over 100 individuals encountered (Shirihai 2008b, Bird 2012). Nevertheless, determining population size and trends, threats to the species and its conservation status are all reliant on locating the breeding grounds. This is regarded as the pre-eminent research action for this species (Birdlife International 2012, Bird 2012). Just one targeted search for its breeding grounds on land has been attempted (Bird 2012), but a number of more general terrestrial bird surveys have been conducted in the Bismarck Archipelago that have failed to record any sign of burrow-nesting seabirds (see Mayr and Diamond 2001).

In this paper we: (i) assess the scant information concerning the taxonomic validity of Beck's Petrel; (ii) collate, update and review all records of Beck's Petrel; (iii) examine the extent and findings of avifaunal surveys in the Bismarck Archipelago and northern Solomon Islands; (iv) review potential breeding sites; and (v) prescribe research actions needed to inform the conservation of the species.

\section{Taxonomic status of Beck's Petrel}

According to molecular evidence, Bretagnolle et al. (1998) concluded that the two Tahiti Petrel subspecies Pseudobulweria rostrata trouessarti from New Caledonia and P. r. rostrata from Polynesia, do not deserve species status because of their two distributional extremes, and should be regarded as valid subspecies. Their conclusion was supported both by morphometrics and vocalisations (De Naurois and Erard 1979, Bretagnolle unpubl. data in Bretagnolle et al. 1998). Their analysis did not include becki as no birds have been sound-recorded or handled at breeding grounds so no vocal or genetic samples were available for comparison. Morphometric comparison of three specimens of becki with a sample of the two P. r. rostrata and P. r. trouessarti (Villard et al. 2006) showed no overlap in wing, tail, bill or tarsus measurements (Shirihai 2008a). However, given that vocal and genetic differences are recognised as important cues for determining taxonomic relationships in petrels (Randi et al. 1989, Wink et al. 1993a, b, Bolton 2008) identification of Beck's Petrel's breeding grounds to collect these data and allow comparison with P. r. rostrata and P. r. trouessarti is highly desirable to further clarify the taxonomic status of becki.

\section{Records of Beck's Petrel}

Records at sea

In total, we collated 45 reports of Beck's Petrel, all of which refer to at-sea observations (Table SI in the online supplementary material). Identification of Beck's Petrel at sea is challenging. It cannot be reliably separated from Tahiti Petrel in photographs (Shirihai 20o8b) and descriptions in trip reports published online and verbal descriptions received are often conflicting and confusing (e.g. Collins 2008, 2010, 2011, P. Harrison in litt. 2012, D. Fisher pers. comm.). During personal observations (JB) of Pseudobulweria petrels in Fiji and the Bismarck Sea there were no definitive plumage differences. However, these observations supported the notion in Shirihai (2008b) and Collins (2011) that small becki-type petrels in the Bismarck Sea have a distinctly more rapid and shorter flight action during arcing wind-assisted flight than larger rostrata-type birds.

Given the current uncertainty over the identification of Beck's Petrel in the field we investigated the veracity of each report. Reports were classified as either: (i) confirmed if the bird was taken as a specimen; (ii) of high reliability if the record has been published in a peer-reviewed paper, was based on a multi-observer sighting, or a description was available for review that corroborates the record; and (iii) of low reliability if there was insufficient documentation to support the record, or doubt from the observers. Of 43 confirmed or high reliability records, 40 are from the last five years. 
There may be additional unpublished reports from this period as birdwatchers visiting the archipelago now target this species, with boat charters available to search at sea e.g. MV FeBrina at Walindi Plantation Resort, New Britain (Walindi Plantation Resort 2012).

\section{Records on land}

No records exist of any Beck's Petrels seen or captured on or over land. Steadman et al. (1999) analysed bird bones from five late Pleistocene and Holocene archaeological sites on New Ireland. Represented by a coracoid and carpometacarpus, they identified a Pseudobulweria petrel, either rostrata or becki from Matenbek, southern New Ireland (Figure 1). The petrel bones were estimated to be 6,00o years old (Steadman et al. 1999). Based on their relatively large size, Steadman et al. (1999) concluded that the two bones may represent the Tahiti Petrel. However, their analysis was prior to the collection of the third specimen of becki and the morphometric analyses of Villard et al. (2006) and Shirihai (2008a). Neither species is known to breed currently on New Ireland.

\section{Surveys for petrels in the Bismarck Archipelago and Solomon Islands}

\section{At-sea surveys}

Pterodroma and Pseudobulweria petrels are highly dispersive covering large distances (hundreds of kilometres) during foraging trips in search of low-density or patchily distributed prey (Warham 1996). They are normally encountered singly but aggregations can occur at sea when a prey source is identified or when breeding birds gather close to shore in the early morning and evening having visited colonies during the hours of darkness (Warham 1996). This latter behaviour is

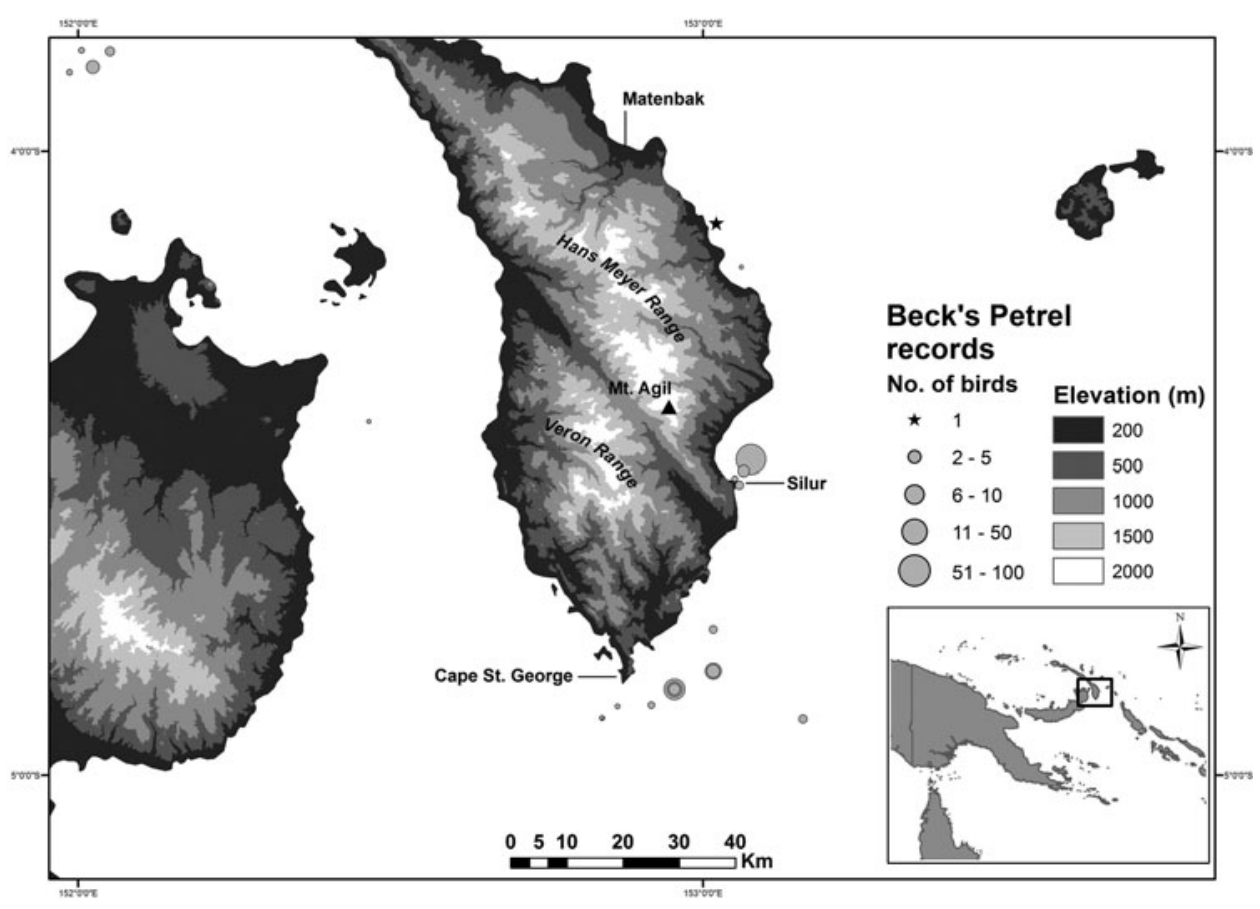

Figure 1. Key locations in Southern New Ireland reported in the text, with observations of Beck's Petrel. 
considered to be a strong indication that birds breed nearby (D. Forsell pers. comm. to Simons et al. 2006). Therefore evaluating at sea observations can help to pinpoint potential breeding grounds. It is also important to review the coverage of at sea surveys to evaluate whether apparent hotspots of Beck's Petrel sightings are likely to represent genuine high-use areas or if they simply correlate with survey effort, in which case there may be other high-use areas awaiting discovery in poorly surveyed parts of the region.

Of the confirmed and high veracity records in Table $\mathrm{S}_{1}, 11$ refer to records of 10 or more individuals. All but two of these were observations of birds attracted to chum; akin to Warham's (1996) description of petrel aggregations formed when a prey source has been identified. The remaining two records are of early morning encounters of birds massed close to land performing circulatory flights, more indicative of nearby breeding.

When mapped, the clustering of Beck's Petrel records around southern New Ireland is evident (Figure 2). The poor quality of effort data does not permit statistical analysis of the relationship between observations and at-sea survey effort, but a simple overlay indicates the areas where most Beck's Petrels have been recorded overlap strongly with the areas that have been surveyed most frequently.

\section{Terrestrial surveys}

The only speculation to date as to where Beck's Petrel breeds suggests the mountains of southern New Ireland (Shirihai 2008a), especially Mt. Agil (Bird 2012), Bougainville (Hadden 1981), or the Solomon Islands (Murphy and Pennoyer 1952). Within the wide region of the Bismarck

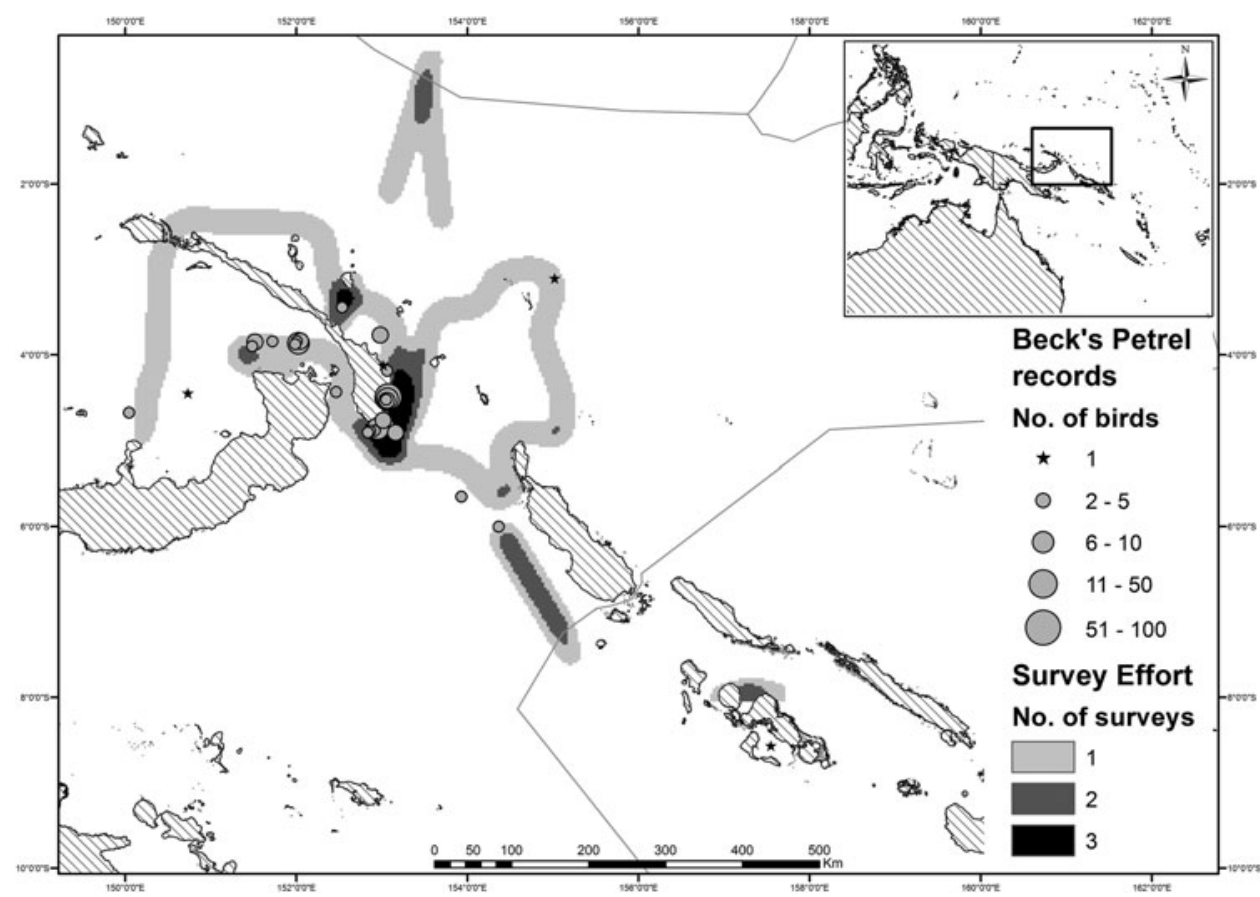

Figure 2. Records of Beck's Petrel overlain on at-sea survey distribution. Survey distribution is derived from tracks logged by JB in February/March 2012; sunrise and sunset waypoints collected on Western Pacific Odyssey trips in 2009 and 2010 (C. Collins in litt.) and digitised from Shirihai (2008a). 
Archipelago and Solomon Islands there has been extremely limited terrestrial survey effort focused specifically on locating petrel colonies. In particular there has been very little spot-lighting at night; a method which has routinely been used to locate elusive petrel species at their nesting grounds (Warham 1996). Bird (2012) performed ad-hoc interviews in coastal villages in southern New Ireland to gather any local knowledge of nesting petrels, completed pre-dawn to early morning and late-afternoon to post-dusk coastal sea-watches for birds returning to land, and spot-lighted for seabirds at sub-optimal foothill sites while playing Tahiti Petrel calls. This survey received no compelling reports of petrel-like birds on land, with no harvesting of seabirds taking place, and no evidence of birds grounded at lights in villages (Bird 2012).

The only documented reports of burrow-nesting seabirds on land in the Bismarck Archipelago and Solomon Islands are those in Hadden (2004) of Heinroth's Shearwater Puffinus heinrothi breeding in the Crown Prince Range, Bougainville, although this species is also believed to breed on Kolombangara (Buckingham et al. 1995); and the original specimens of Heinroth's Shearwater collected on Watom (BirdLife International 2012). Hadden (2004) lists Beck's Petrel for Buka and Bougainville but this appears to be based only on the type specimen collected north of Buka. There has apparently been no petrel-focused survey effort within the region that has used proven survey techniques such as spot-lighting from mountain peaks at night, or playback of Pterodroma or Pseudobulweria calls. Any such techniques will be hampered by a lack of information on the timing of breeding for targeted species, which for Beck's Petrel is poorly known.

Mayr and Diamond (2001) catalogued all bird surveys that took place in the islands of the Bismarck Archipelago and the Solomons up to 2000. Mapping the level of effort by total number of surveys (Figure 3 ) it is evident that larger islands have received greater survey effort than

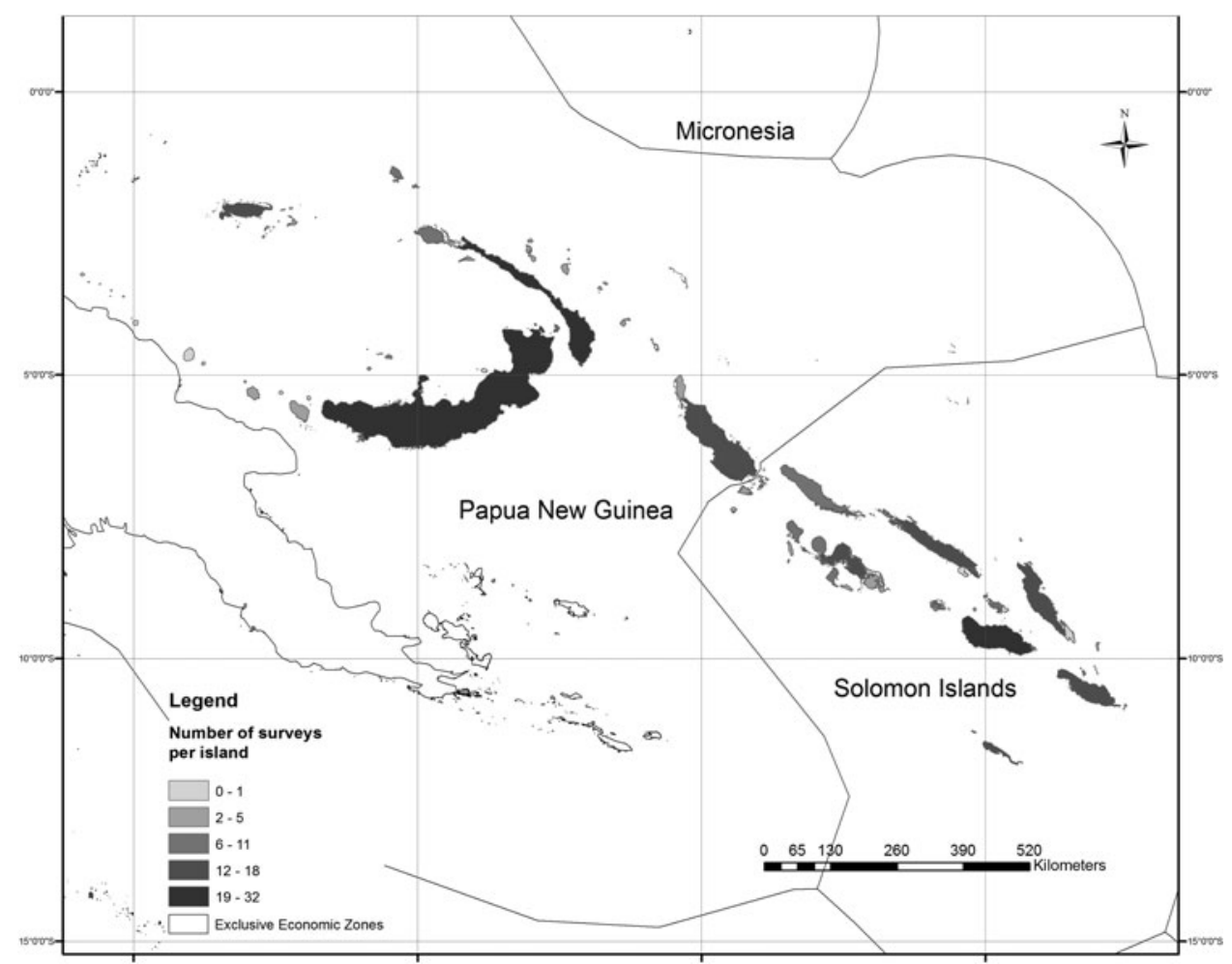

Figure 3. Total number of surveys per island documented in Mayr and Diamond (2001). 
small islands, and large islands in the Bismarck Archipelago have been visited more often and more recently than large islands in the Solomons. Many small satellite islands have never been surveyed for birds and no surveys have been temporally spaced within a calendar year. Although it is not apparent in Mayr and Diamond (2001), few surveys have visited the upland interiors of the larger islands (G. Dutson pers. comm.), so along with the more remote off-islands and satellite islands these are the least explored parts of the region. One notable exception is the biodiversity assessment of Southern New Ireland, which spent one week above 1,800 m near the summit of the Hans Meyer Range during January and February 1994 (Beehler and Alonso 2001). However, as with other surveys, spot-lighting and audio surveys at night were not conducted.

\section{Discussion}

Very little is known of the status of Beck's Petrel. Recent observations at sea suggest it may be relatively common compared, for example, to Fiji Petrel which has been recorded far less despite a similar or higher level of survey effort (D. Watling pers. comm. 2010). The reason Beck's Petrel went unrecorded for so long may reflect the limited survey effort within its range during that period rather than rarity. Nevertheless, to date, no single survey has confirmed that the population is larger than the threshold of 250 mature individuals which, together with a presumed declining trend, qualify the species as "Critically Endangered" on the IUCN Red List.

\section{Location of the nesting grounds}

Shirihai (2008a) observed Beck's Petrels close to land (1-2 km) at Cape St. George, New Ireland in the late afternoon in August, 2007, leading him to speculate that birds are breeding in the Veron Range or Hans Meyer Range of southern New Ireland (Figure I). A more precise area could not be pin-pointed because no behaviours exhibited by birds approaching breeding colonies such as rafting, vocalising or circulatory flights (Warham 1996) were observed. Birds seen by Bird (2012) in March, 2012 in the same area and at the same time of day as Shirihai's observations were all in active flight heading out to sea towards Buka, not approaching land.

Of all records to date, the strongest indication of nearby breeding comes from the aggregation of 100 or more individuals performing non-directional circulations, rather than actively foraging or dispersing, within $2 \mathrm{~km}$ of shore (Bird 2012). These birds were present in the early morning at Silur, southern New Ireland on 13 and 14 March 2012 (Table S1). This site is adjacent to the highest peak in the Hans Meyer Range, and all of New Ireland, Mt Agil at over 2,00o m. The upper elevations of Mt Agil and the Hans Meyer Range are dominated by perpetually wet mossy forest with a low canopy and tangled understory vegetation (Beehler and Alonso 2001). It is approximately $11 \mathrm{~km}$ from the summit to the sea. The characteristics of this area are very similar to Mt Lata, Ta' $u$, American Samoa, where a large colony of Tahiti Petrels is known to breed $\left(\mathrm{O}^{\prime} \mathrm{Connor}\right.$ and Rauzon 2004) and conforms with one type of locality likely to suit Beck's Petrel (see references below to Tahiti Petrel breeding on low-lying islands).

Tahiti Petrels forage within the vicinity of their colonies during the breeding season (Onley and Scofield 2007). Assuming Beck's Petrel is similar, the clustering of observations (Figure 2) and in particular those of birds exhibiting behaviours associated with approaching and departing the colony, strongly suggest southern New Ireland hosts a breeding population. The most likely site is Mt Agil owing to the location of at sea observations and the characteristics of the site itself. This is potentially supported by the discovery of Pseudobulweria bones in archaeological deposits from Matenbak, c.50 km to the north (Steadman et al. 1999).

A major corollary of the modern day distribution of petrels worldwide is the occurrence of mammals (Warham 1996, Onley and Scofield 2007). Historic distributions were often shaped by native mammal distributions with procellariiformes occurring on mammal-free islands (Onley and Scofield 2007). Distributions have been modified subsequently by the spread of invasive mammals transferred by humans, which have led to a spate of island extirpations and the 
extinction of several species. Importantly what little information is available on the presence of petrels on New Ireland contradicts this trend. Steadman et al. (1999) makes two important points: 1) according to the archaeological record New Ireland has a lower proportion (24\%) of extinct/extirpated species than islands to the east in Oceania which he postulates may be related to the presence of indigenous rodents Melomys rufescens and Rattus mordax sanila. In Remote Oceania, birds evolved without native mammalian predators, leading to naïveté and vulnerability to predation when humans and associated non-native mammals arrived. Evolving alongside native rodents exposed New Ireland's birds to potential predation from terrestrial animals in pre-human times (Steadman et al. 1999). 2) Humans had colonised the Bismarck Archipelago and Solomon Islands by 35,000-30,000 years ago. Thus, unlike in Remote Oceania, where human arrival in the late Holocene was clearly devastating to indigenous birds, the Lapita peoples who moved across the Bismarck Archipelago and Solomons about 3,500 years ago found a flora and fauna that already had withstood tens of millennia of human activity. At Matenbek where Steadman et al. (1999) identified Pseudobulweria remains deposits reveal two phases of human occupation from 20,000 to 18 , 000 B.P., after which the site was abandoned and then reoccupied from 9,000 to 6,000 B.P. Species of mammals brought to New Ireland by humans appear at the sites after 19,000 B.P. These are phalangers Phalanger orientalis, Spilocuscus maculatus, wallabies Thylogale brunii, rats Rattus praetor, R. exulans, pigs Sus scrofa, and dogs Canis familiaris. The Pseudobulweria bones were dated to 6,00o B.P. suggesting that, if petrels were native to New Ireland (as seems likely), they had already persisted for 13,000 years in the presence of non-native mammals. Since then, cats Felis catus have been introduced but these appear still to be rare at higher elevations, and mammal surveys in 1994 did not record black rat Rattus rattus or brown rat $R$. norvegicus (Beehler and Alonso 2001). Therefore, there is little direct evidence to suggest invasive mammals will have had an adverse impact on birds breeding at high altitude on New Ireland.

We have presented above compelling evidence that Beck's Petrel may well breed on New Ireland, Papua New Guinea. However, there may be other breeding sites within the Bismarck Archipelago and Solomon Islands. Plausible locations are the relatively under-surveyed islands of Western Province, Solomon Islands (Figure 3), where a 1929 specimen was collected east of Rendova, and where Heinroth's Shearwater is thought to nest, although no confirmation has been obtained (Buckingham et al. 1995). If Heinroth's Shearwater, a presumed burrowing species, remains extant on an island it is possible that conditions could support other burrow-nesting petrels, as is the case with Tahiti Petrels nesting within Shearwater colonies in the Southern Lagoon of New Caledonia (Benoit and Bretagnolle 2002). Therefore Bougainville and adjacent Buka are also plausible nesting sites for Beck's Petrel. Finally, Tahiti Petrel is known to nest on low-lying islands (Benoit and Bretagnolle 2002). Such small and low-lying islands in Papua New Guinea and the Solomons have received less survey effort than the main islands. Any mammal-free motu in atolls east of the main islands of the Bismarck Archipelago and Solomons could potentially support undiscovered petrel populations.

\section{Threats}

Although Beck's Petrel may prove to be commoner than feared, it is almost certainly rarer today than it was historically. Drawing comparisons with other procellariiformes breeding in the Pacific the assumption that the population is probably declining (Birdlife International 2012) is a sensible one. As little is known about the ecology of Beck's Petrel we can only guess as to the nature and extent of any threats.

Invasive species are recognised as the greatest threat to seabirds, invariably active at breeding sites (Croxall et al. 2012). While we have outlined why the impact of invasive species on New Ireland may have been less acute than elsewhere in the Pacific, the current distribution of Beck's Petrel is probably limited geographically and altitudinally by invasive species. Species introduced since European exploration, like feral cats, are a potentially serious threat to extant populations. Any surveys for this species would need to be aware of 'opening-up' of forest paths to the arrival 
of feral animals such as pigs and cats. These 'new' invasions of abundant 'lowland distributed' feral animals have been documented for remote breeding Newell's Shearwater Puffinus newelli in Kauai'i, Hawaiian Islands (Duffy 2010).

We presume that Beck's Petrel nests in dense forest cover like other petrels in the tropical Pacific. Such areas are relatively free from human disturbance and hunting pressure is likely to be low. Invasive species generally occur at lower densities here than in modified habitats. Therefore broad-scale habitat conversion represents a potential threat, although as likely nesting sites are at high elevation, possibly on steep slopes, or on remote islands the likelihood of a direct impact may be low. Forest conversion is occurring rapidly within the region owing to logging, mining and the expansion of oil palm plantations (Buchanan et al. 2008, Pauku 2009). It is projected that all lowland forest in the Solomon Islands will have been cleared by 2015 (Pauku 2009). Identifying nesting colonies will allow assessment of likely impacts from current and proposed mining, logging and oil palm concessions.

\section{Future conservation actions}

At this stage conservation actions relate to research rather than recovery actions. Locating the nesting grounds is imperative (BirdLife International 2012, Bird 2012). To this end there are a number of active field-based activities that should be pursued, but also more passive (and much cheaper) desk-based exercises that could inform future searches. These suggested actions have been loosely ordered to help readers visualize a systematic programme that would address highest priority needs first and identify subsequent priorities for the future.

1) Although the complete absence of any Beck's Petrel records from land precludes it, species distribution modelling could be attempted for Tahiti Petrel for which there is sufficient data on colony distribution. This might allow areas apparently appropriate for Pseudobulweria nesting to be identified in the Bismarck Archipelago and Solomon Islands. Similarly additional datasets exist, but were unavailable for our analyses, that could improve modelling the at-sea distribution of Beck's Petrel and inform future boatbased searches for the species outside the regularly visited areas identified in Figure 2. Even without this exercise the little visited seas around Rendova are an obvious target.

2) Spot-lighting at night has been used routinely to identify petrels on land at or near their nesting grounds (Warham 1996). Employing this technique within the putative range of Beck's Petrel is an obvious next step, particularly at Mt Agil in New Ireland. However, many years of similar effort yielded very few captures of Fiji Petrel on Gau, Fiji (Priddel et al. 2008, O'Connor 2012). Additionally, the training for local capacity to carry out such activities is difficult without experience in either the technique or its application to nocturnal seabirds, requiring significant time by experienced practitioners. Without a definite focused area for its application, the 'nil-report' for nights of effort dramatically reduces the effectiveness of this survey method in unsupervised programmes.

3) More successful has been the use of trained dogs to search for burrows. This focused effort requires a better understanding of potential smaller breeding islands and regions within larger landmasses that has yet to be determined. However, the application of detector dogs requires lead-in time for the procuring of suitable dogs. Substantial commitment is also needed by selected local residents. The local commitment is not only in the training to receive a suitably trained dog but in the on-going care and maintenance of the $\operatorname{dog}(\mathrm{s})$ and follow-up efforts to ensure they retain their searching skill-sets.

4) As is apparent from 2) and 3) above, in any recovery programme one of the highest priorities is to build capacity within key local communities surrounding a breeding site. With the breeding locations currently unknown and uncertainty surrounding their possible locations this aspect of the programme remains inactive. A strong current NGO presence within communities would be invaluable for addressing this issue. 
5) A recent reassessment of the 2007 specimen (Table S1) confirmed it is a juvenile (G. Taylor in litt.). The specimen was collected in August, implying a breeding season beginning in March/ April. Refining this breeding season is complicated by rostrata being known to produce fledglings at other locations almost year-round (Villard et al 2006). Nevertheless, trapping of Becks Petrel at sea to determine breeding status (through presence of brood patches) may be warranted to corroborate this to identify optimal timing for any labour intensive land-based surveys. The employment of small craft in chumming for species less likely to approach large vessels has facilitated capture of individuals of other species at sea and its application to Beck's Petrel should be investigated. Success in the at-sea capture of the species would also allow for the attachment of two-stage transmitters for radio-tracking. However the terrain and elevation of potential breeding areas creates further complexities. Substantial effort by aircraft-based trackers with extensive experience with signal attenuation, impacts of vegetation and terrain on any search effort would be required for success using this technique. Obtaining morphometrics, vocal and tissue samples from any live specimens would be invaluable in determining the case for the specific status of Beck's Petrel from its close relatives.

6) Automated audio recording devices are being employed for surveys for New Zealand Storm-petrel Oceanites maorensis and Ashy Storm-petrel Oceanodroma homochroa (C. Gaskin, pers. comm., M. McKown pers. comm.). These have the potential to reduce the need for surveyors to be on-site to check for the presence of nocturnal seabirds. However, it is highly likely that Beck's Petrel will only vocalise at the breeding colony: if these are disbursed over large areas, similar to Magenta Petrel, then audio surveys will have limited value. Given the potential remoteness of the breeding areas of Beck's Petrel audio devices could be deployed following initial on-ground surveys.

7) When a colony site is identified specific research needs to address general ecology and breeding biology of Beck's Petrel. It will be essential to identify and ameliorate land-based threats causing egg, chick or adult mortality. Parameterising environmental factors particular to the site location of the colony will allow identification of comparable sites within the potential breeding range that could support additional colonies. Determination of the species' vocalisations will greatly assist discovery of additional breeding sites and help to resolve taxonomic relationships. An assessment of population size and trends will be essential in future management of this species.

8) Given that the threats to Beck's Petrel are unknown and may be either on land or at sea, revealing at-sea movements by deploying geolocation devices may provide vital clues to threats away from breeding colonies. However, as with other proposed actions, the application of geolocation devices, applied and removed at nest burrows, can only be attempted once the breeding sites have been identified.

\section{Supplementary Material}

The online supplementary materials for this article can be found at journals.cambridge.org/bci

\section{Acknowledgements}

We are grateful to Chris Collins, Guy Dutson, Arjan Dwarshuis, David Fisher, Chris Gaskin, Peter Harrison, Matthew McKown, Paul Scofield, Hadoram Shirihai, Graham Taylor and Dick Watling for the provision of records and comments. Particular thanks to the editors of BCI and two anonymous referees who provided invaluable comments to improve the structure and content of this manuscript. We are also indebted to the Mohammed Bin Zayed Species Conservation Fund, the Global Greengrants Fund and the Aage. V. Jensen Charity Foundation for their financial support. 


\section{References}

Beehler, B. M. and Alonso, L. E., eds. (2001) Southern New Ireland, Papua New Guinea: A biodiversity assessment. Washington, DC: Conservation International. (RAP Bulletin of Biological Assessment 21).

Benoit, M. P. and Bretagnolle, V. (2002) Seabirds of the Southern Lagoon of New Caledonia: distribution, abundance and threats. Waterbirds 25: 202-213.

Bird, J. P. (2012) Targeted searches to identify nesting grounds of Beck's Petrel Pseudobulweria becki. Notornis 59: 189-193.

BirdLife International (2012) IUCN Red List for Birds. Downloaded from http://www. birdlife.org on 06/07/2012.

Bolton, M., Smith, A. L., Gómez-Díaz, E., Friesen, V. L., Medeiros, R., Bried, J., Roscales, J. L. and Furness, R. W. (2008) Monteiro's Storm Petrel Oceanodroma monteiroi: a new species from the Azores. Ibis 150: 717-727.

Bretagnolle, V., Attié, C. and Dixon, T. J. (1998) Cytochrome-b evidence for validity and phylogenetic relationships of Pseudobulweria and Bulweria (Procellariidae). Auk 115: 188-195.

Brooke, M. (2004) Albatrosses and petrels across the world. Oxford, UK: Oxford University Press.

Buchanan, G. M., Butchart, S. H. M., Dutson, G., Pilgrim, J. D., Steininger, M. K., Bishop, K. D. and Mayaux, P. (2008) Using remote sensing to inform conservation status assessment: estimates of recent deforestation rates on New Britain and the impacts upon endemic birds. Biol. Conserv. 141: 56-66.

Buckingham, D. L., Dutson, G. C. L. and Newman, J. L. (1995) Birds of Manus, Kolombangara and Makira (San Cristobal) with notes on mammals and records from other Solomon Islands. Report on the Cambridge Solomons Rainforest Project 1990.

Carboneras, C. (1992) Order Procellariiformes. Pp. ${ }^{198-278}$ in J. del Hoyo, A. Elliot and J. Sargatal, eds. Handbook of the birds of the World. Vol. 1. Ostrich to ducks Barcelona: Lynx Edicions.

Christidis, L. and Boles, W. E. (1994) The taxonomy and species of birds of Australia and its territories. Melbourne: Royal Australasian Ornithologists' Union (RAOU Monogr. 2).

Christidis, L. and Boles, W. E. (2008) Systematics and taxonomy of Australian birds. Collingwood, Australia: CSIRO Publishing.

Collins, C. (2008) Western Pacific Odyssey 2008 Trip Report. Downloaded from http:// www.wildwings.co.uk/tripreports.html on 11/06/2012.

Collins, C. (2010) Western Pacific Odyssey 2010 Trip Report. Downloaded from http:// www.wildwings.co.uk/tripreports.html on 11/06/2012.

Collins, C. (2011) Western Pacific Odyssey 2011 Trip Report. Downloaded from http:// www.wildwings.co.uk/tripreports.html on 11/06/2012.

Croxall, J. P., Butchart, S. H. M., Lascelles, B., Stattersfield, A. J., Sullivan, B., Symes, A. and Taylor, P. (2012). Seabird conservation status, threats and priority actions: a global assessment. Bird Conserv. Internatn. 22: 1-34.

De Naurois, R. and Erard, C. (1979) L'identité sub-spécifique des populations néocaledoniénnes de Pterodroma rostrata Peale 1848 . Oiseau et la Revue Française d'Ornithologie 49: 235-239.

Dickinson, E. C. (2003) The Howard and Moore complete checklist of the birds of the world. 3 rd edition. London: Christopher Helm.

Duffy, D. C. (2010) Changing seabird management in Hawai' $\mathrm{i}$ : from exploitation through management to restoration. Waterbirds 33: 193-207.

Hadden, D. (1981) Birds of the North Solomons. Papua New Guinea: Wau Ecology Institute. (Handbook no. 8).

Hadden, D. (2004) Birds and bird lore of Bougainville and the North Solomons. Queensland, Australia: Dove Publications Pty. Ltd.

Harrison, P. (1985) Seabirds: An identification guide. Revised edition. London: Croom Helm.

Imber, M. J. (1985) Origins, phylogeny and taxonomy of the gadfly petrels Pterodroma spp. Ibis 127: 197-229. 
Jouanin, C. and Mougin, J.-L. (1979) Order Procellariiformes. Pp 48-121 in E. Mayr and G. W. Cottrell, eds. Checklist of birds of the world, vol.1. Second edition. Cambridge, Massachusetts: Museum of Comparative Zoology.

Marchant, S. and Higgins, P. J., coordinators. (1990) Handbook of Australian, New Zealand and Antarctic birds. Vol 1A. Ratites to Ducks. Melbourne: Oxford University Press.

Mayr, E. and Diamond, J. (2001) The Birds of Northern Melanesia: Speciation, ecology and biogeography. New York: Oxford University Press.

Murphy, R. C. (1928) Birds collected during the Whitney South Sea Expedition. American Museum Novitates 322: 1-5.

Murphy, R. C. and Pennoyer, J. M. (1952) Larger petrels of the genus Pterodroma. American Museum Novitates 1580: $1-44$.

O'Connor, E. (2012) Fiji Petrel conservation project. Quarterly report Jan-Mar 2012. Suva, Fiji: NatureFiji.

O'Connor, P. J. and Rauzon, M. J. (2004). Inventory and monitoring of seabirds in National Park of American Samoa. Final Report. Technical Report 136. University of Hawai'i at Manoa.

Onley, D. and Scofield, P. (2007) Albatrosses, petrels and shearwaters of the world. London: Christopher Helm.

Pauku, R. L. (2009) Solomon Islands forestry outlook study - Asia-Pacific forestry sector outlook study II. Bangkok, Thailand: Food and Agriculture Organization of the United Nations Regional Office for Asia and the Pacific. (Working Paper No. Apfsos Ii/Wp/ 2009/31).

Priddel, D., Carlile, N., Moce, K., and Watling, D. (2008) Review of the records and recovery actions for the critically endangered Fiji Petrel Pseudobulweria macgillivrayi. Bird Conserv. Internatn. 18: 381-93.

Randi, E., Spina, E. and Massa, B. (1989) Genetic variability in Cory's Shearwater (Calonectris diomedea). Auk 106: 411-418.

Shirihai, H. (2008a) Rediscovery of Beck's Petrel Pseudobulweria becki, and other observations of tubenoses from the Bismarck Archipelago, Papua New Guinea. Bull. Brit. Ornithol. Club 128: 3-16.

Shirihai, H. (2008b) Tubenoses at the Bismarck Archipelago: Surveying at sea populations of the Beck's Petrel; in search of the Fiji-like Petrel Expedition \# 3. Unpublished report, August 2008.

Sibley, C. G. and Monroe, B. L. (1990) Distribution and taxonomy of birds of the world. New Haven, USA: Yale University Press.

Simons, T. R., Lee, D., Janey, J. C., Gerwin, J., Rimmer, C., Collazo, J., Klavins, J., Goetz, J. E., Fernandez, E. M., Browning, B., Patteson, B. and Hylton, R. A. (2006) Draft - Status Report on the Black-Capped Petrel (Pterodroma Hasitata). Prepared for U.S. Fish and Wildlife Service, Atlanta, GA, USA.

Steadman, D. W., White, J. P. and Allen, J. (1999) Prehistoric birds from New Ireland, Papua New Guinea: Extinctions on a large Melanesian island. Proc. Natl. Acad. Sci. 96: 2563-2568.

Villard, P., Dano, S. and Bretagnolle, V. (2006) Morphometrics and the breeding biology of the Tahiti Petrel Pseudobulweria rostrata. Ibis 148: 285-291.

Warham, J. (1990) The petrels: Their ecology and breeding systems. London: Academic Press.

Warham, J. (1996) The behaviour, population biology and physiology of the petrels. London: Academic Press.

Walindi Plantation Resort (2012) MV FeBrina live-aboard website. Downloaded from http://www.walindi.com/ on 20/07/ 2012.

Wink, M., Heinrich, P., Kahl, U. and Swatschek, I. (1993a) Inter- and intraspecific variation of the nucleotide sequence of the cytochrome b gene in Cory's Shearwater (Calonectris diomedea), Manx Shearwater (Puffinus puffinus) and the Fulmar (Fulmarus glacialis). Zeitschr. Naturforsch. 48c: 504-509.

Wink, M., Heiorich, P. and Ristow, D. (1993b) Genetic evidence for speciation of the Manx Shearwater Puffinus puffinus and Mediterranean Shearwater Puffinus yelkouan. Vogelwelt 114: 226-232. 
JEREMY P. BIRD*, MARK G. R. MILLER

BirdLife International, Wellbrook Court, Girton Road, Cambridge CB3 oNA, UK.

NICHOLAS CARLILE

Threatened Fauna Ecology, Biodiversity \& Landscapes Science Branch, Science Division, Office of Environment \& Heritage, Dept. of Premier \& Cabinet, 43 Bridge Street Hurstville NSW 2220 Australia.

*Author for correspondence; e-mail: jezbird@gmail.com

Received 16 January 2013; revision accepted 17 July 2013 Published online 29 October 2013 